\title{
Vindication is sweet, but not sufficient
}

It has been a long, hard decade for research in the United States where a preoccupation with politically motivated accusations of fraud has damaged the reputations of some of the world's leading scientists, while calling the integrity of the entire biomedical enterprise into disrepute.

However, a recent ruling by the Appeals Board of the
That, finally, is what the Appeals Board provided. After weeks of hearings on the Imanishi-Kari case that resulted in a transcript 6500 pages long, the Board ruled that the ORI's case against her was based on "unsupported assumptions" for which it could not produce convincing evidence.

The result of a hearing in the Popovic case was a similarly absolute judgment by the Appeals Board: "One might anticipate that from all this evidence [presented by ORI], after all the sound and fury, there would be at least a residue of wrongdo-
Department of Health and Human Services, which vindicates Thereza Imanishi-Kari and clears her of charges of fabricating data in a 1986 Cell paper coauthored by David Baltimore, should be the last bit of evidence we need that the whole system for investigating allegations of fraud is, itself, the next best thing to fraudulent. This is the time to redesign the system from the ground up.

Two US cases have dominated the news around the world. Allegations that Imanishi-Kari made up data were transmuted by the press into the "Baltimore" case because her uncharged coauthor, a Nobel laureate of international standing, made better headlines than she. The other sensational case - the "Gallo affair" consisted of charges that Robert C. Gallo and his colleague, Mikulas Popovic, falsified data in a paper published in Science in 1984 on the AIDS virus.

For 10 seemingly endless years, the tenor of congressional hearings, leaks from the Office of Research Integrity (ORI) and its various advisory panels, and news accounts all added up to a presumption of guilt. Popovic, who lacked tenure, lost his job in Gallo's laboratory at the National Institutes of Health. Imanishi-Kari's tenure review at Tufts University was put on hold. And Baltimore's allegedly bad judgment in defending his coauthor was used as an excuse to drive him from the presidency of Rockefeller University, when the real issue was his plan to enhance the independence of junior faculty.

The tragedy in ruined reputations and lost research time lies in the secret procecdings that the ORI used in the name of scientific truth-seeking. The accused were not allowed to see all of the evidence against them or to challenge their accusers face to face. That, ORI said, would cast the resolution of supposedly purely scientific disputes too much in the legal mold. But an allegation of fraud is an allegation of illegal activity and should be handled with all of the procedural protections of the law. ing. That is not the case. . . ORI did not prove that the Science paper contains any untrue statements or data, much less that it contains intentional falsifications."

It is particularly pertinent to focus on the importance of hard evidence in fraud cases in light of an appalling proposal on "Integrity and Misconduct in Research" that has just emanated from a commission of the very Department of Health and Human Services whose research integrity office has performed so dismally. The commission, in the name of turning all-to-human scientists into superhuman paragons of virtue, would rewrite the definition of fraud and misconduct to include behavior that simply isn't nice - such as "failing to recognize the intellectual contributions of others."

Its definitions are so broad as to invite scientists to level accusations against one another for almost anything that offends. Stating as a fundamental principle that "scientists be truthful and fair in the conduct of research and the dissemination of results," the commission recommends "leaving it to the evolution of ethical standards and 'case law" to make ultimate decisions about which forms of alleged "misbehavior" are serious enough to warrant government sanctions. In other words, define misconduct broadly and imprecisely and open the door to the courts.

Nothing could be more damaging to science. After all, it is the public purse that supports most biomedical research. And it is in the public interest to have scientists doing science, not squabbling in court over petty misdeeds, real or imagined. Sound laws against fraud and data fabrication are already on the books. The Gallo and Baltimore cases merely prove that had they been rigorously applied in the first place, those cases could have been disposed of in a lot fewer than 10 years. And a lot less damage would have been done to both innocent persons and to research.

- Barbara J. Culliton 